\author{
Abstracta Iranica \\ Abstracta Iranica Revue bibliographique pour le domaine irano-aryen \\ Volume 34-35-36 | 2017 \\ Comptes rendus des publications de 2011-2013
}

\title{
Florence Jullien. Une pratique religieuse en médiation culturelle entre chrétiens et mazdéens
}

\section{Marie-Joseph Pierre}

\section{(2) OpenEdition}

Journals

Édition électronique

URL : http://journals.openedition.org/abstractairanica/41931

DOI : 10.4000/abstractairanica.41931

ISSN : 1961-960X

Éditeur :

CNRS (UMR 7528 Mondes iraniens et indiens), Éditions de l'IFRI

Référence électronique

Marie-Joseph Pierre, «Florence Jullien. Une pratique religieuse en médiation culturelle entre chrétiens et mazdéens », Abstracta Iranica [En ligne], Volume 34-35-36 | 2017, document 24, mis en ligne le 30 décembre 2016, consulté le 03 octobre 2020. URL : http://journals.openedition.org/abstractairanica/ 41931 ; DOI : https://doi.org/10.4000/abstractairanica.41931

Ce document a été généré automatiquement le 3 octobre 2020.

Tous droits réservés 


\title{
Florence Jullien. Une pratique religieuse en médiation culturelle entre chrétiens et mazdéens
}

\author{
Marie-Joseph Pierre
}

\section{RÉFÉRENCE}

Florence Jullien. « Une pratique religieuse en médiation culturelle entre chrétiens et mazdéens ». Orientalia Christiana Periodica, 79/2, 2013, p. 337-353.

1 Cet article est consacré à l'étude d'une pratique anthropologique frontière entre magie et liturgie en milieu chrétien syriaque, celui du recours à une "pâte de reliques ». Il examine comment les chrétiens qui l'utilisèrent se sont posés en hommes de pouvoir et en acteurs influents de la vie sociale sur le territoire iranien, spécialement auprès des populations zoroastriennes. Au-delà des modes d'écriture, il semble que cet usage rituel ambigu ait joué un rôle de médiateur culturel, conduisant à un dépassement des clivages religieux entre chrétiens et mazdéens.

\section{AUTEURS}

\section{MARIE-JOSEPH PIERRE}

Directrice d'Études honoraire, EPHE 